\title{
Financial Technologies of International Banking Regulations
}

\author{
G.S. Panova ${ }^{1}$ \\ *Corresponding author: gpanova@mail.ru. \\ ${ }^{1}$ MGIMO-University, Moscow, Russia
}

\begin{abstract}
The author considers the problems of banking regulation in the context of globalization. An analysis of relevant issues indicates the need to improve financial technologies for banking regulation. Basel innovations, designed to ensure the stability and uninterrupted operation of the global banking system, have led to the creation of counter-innovations by the banking sector. Basel Accords led to the development of the so-called "regulatory rally", when increasingly sophisticated methods of regulation gave rise to increasingly inventive ways to protect the gains of the banking business. These ways sometimes became an indirect source of rising risks, and were initially taken as effective protection against these risks. The author analyzes the main advantages and disadvantages of the latest Basel Accords on Banking Supervision (Basel III) and identifies specific directions for its improvement, taking into account current practices of national and international approaches to regulating the activities of credit organizations 10 years after the global financial and banking crisis. The importance of the study is determined by the need to develop financial technologies for international banking regulations, as well as theoretical and methodological approaches that determine the interconnectedness and interdependence of financial markets. It is also important to evaluate the effectiveness of measures to regulate the activities of financial and credit institutions at the national and international levels to develop strategies and tactics for the optimal progressive development of financial markets. The purpose of the study is to develop theoretical and methodological approaches to assessing the impact of international standards on activities of Russian credit organizations.
\end{abstract}

Keywords: Basel III, financial technology, banking regulation.

\section{Introduction}

The global financial and economic crisis of 2007-2009 drew particular attention to exposure of the banking sector to systemic risk, which undermines the stability of financial markets. The changes in world financial markets in recent years, such as increased competition, globalization, new information technologies, new high-tech and structured banking products have lead to increased risks. As a result, there is a need for standardization and tightening of requirements to financial stability of financial and credit institutions. In the course of transition of the domestic banking system to international accounting standards, implementation of the recommendations of Basel Accords (Basel II and Basel III), Russia's accession to the WTO, the most urgent task was to provide banking management with analytical information reflecting the influence of various factors on the stability of financial markets. For Russian commercial banks, most of which are still inferior to leading foreign financial and credit institutions in terms of the size of the banking business, the solution of problems ensuring their financial stability is especially relevant. The constantly changing market environment, the volatility of market conditions, the place and role of banks in the economy, as well as the insufficient knowledge of the issues of financial stability of banks in the globalized economy, indicate the relevance of the issues raised. The development of financial markets has a direct impact on the state of the world economy and national economies of individual countries. In the current stage of development of the global economy, financial and credit institutions are urgently faced with the question of minimizing risks associated with the foreign economic activity of their clients (foreign exchange, interest, credit, operating, etc.). An analysis of the opportunities for banks to reduce risks and ensure stable returns in the post-crisis period determines the relevance of the issues raised.

\section{Problem Statement}

Regulation of global financial markets is interconnected with a complex of problems and challenges, including contradictions in state regulation of banking at the national and global levels, as well as contradictions between the global functioning of financial markets and the interests of individual states, contradictions between global financial and credit institutions in the sphere of banking regulation and contradictions between supporters of globalization and / or regionalization of financial markets. Financial regulators strive to solve a three-pronged task, ensuring financial stability in the environment of economic growth and free competition. The consistent implementation of international banking standards in national jurisdictions implies the simultaneous development of free competition and financial innovation.

An urgent problem consists of the fact that international financial institutions, developing international standards and regulating banks' activities, do not have sufficient authority to ensure the implementation of these innovations by national regulators. Similar problems exist at the regional level (within the EU and other associations). Therefore, the ability of the Financial Stability Board (FSB) to monitor the state of global financial markets can be seen as a step forward in solving this problem. However, the Board's tools are very limited. These are: creating a model of behavior, peer review and a 
special set of measures of influence, mainly of a moral nature, as a model for national jurisdictions. At the same time, international institutions seek to expand their influence on national regulators of financial markets. For example, the International Organization of Securities Commissions (IOSCO), as a prerequisite for a member to join the 2001 Memorandum on International Cooperation in Combating Violations in Securities Markets, demands the adoption of national legislation that counteracts market manipulation, which is one of its standard recommendations [1]. Indeed, the lack of coordination and standardization of banking policy at the national level creates the prerequisites for regulatory arbitration. It is no accident that when the Dodd-Frank Act on financial reform and protecting the interests of consumers of financial services was passed, ex-US President B. Obama insisted that other countries adopt similar norms in 2010.

Another problem is the lack of clear rules of subordination between global institutions (for example, the G-20 and the Financial Stability Board), on the one hand, and organizations that develop and establish international standards for the activities of financial and credit institutions (Basel Committee, IOSCO, etc.), on the other hand. For the latter, their own, "specialized" vision of the main tasks and their solutions is often a priority, without taking into accounting the consequences for macroeconomic stability. Overcoming this contradiction, highlighted during the financial and banking crisis of 2008-2009, has become one of important tasks of the modern stage of economic development in the world.

Centrifugal forces also act along with the objective tendencies for coordination and harmonization of financial regulation, whose representatives note that since national financial markets can vary significantly, international standards must be adapted to national specifics. In addition, international standards adopted on a compromise basis, due to the peculiarities of their development, may not always offer the best solution to the problem. Given the differences in the level of maturity of financial markets, as well as cultural, historical, geographical and other features of countries, differences in the operating activities of large and small banks, the very existence of a single international standard for all countries and institutions is being questioned.

To solve pressing problems, the economic press suggested the creation of the World Financial Organization (WFO), by analogy with the World Trade Organization (WTO), to regulate global financial markets, establish international standards for regulation and prudential supervision, monitor their implementation, and create a mechanism to resolve disputes [2].

The idea of adopting an international convention or international cooperation agreement to harmonize regulatory rules in leading financial markets has been repeatedly proposed by the Institute of International Finance (The Institute of International Finance is a research, consulting and information interbank center, created by the largest Western banks in 1983. Its members are more than 180 private banks) [3]. As an argument in favor of creating such a structure, it is possible to use it as an important tool for effective cooperation, able to resolve potential conflicts of interests of individual countries and remove barriers to cross-border business, which is especially important for the largest banks in the world. However, so far this idea has not been discussed at official multilateral meetings. Even for its supporters, it seems to be a very distant prospect since the existence of the IMF and the World Bank partially solves the problem of monitoring financial markets. At the same time, the main reason why it is not possible to create the World Financial Organization as a world regulator with legal and enforcement functions is the unwillingness of national governments to sacrifice part of sovereignty and transfer the right to control their financial markets to an international organization, the decisions of which they cannot fully control. Events 2008-2009 showed that in the event of a crisis, bank rescue was carried out mainly at the expense of national budgets. According to Mervyn King, who runs the Bank of England at that time, financial institutions are global while they are alive, but become national when they are dying [4].

The crisis of 2008-2009, accompanied by the bankruptcy of many banks and the exposure of dishonest behavior of bank employees and top management, led to a drop in confidence in banks. In these conditions, the importance of ethical standards and public interests in the banking business, ensuring accessibility, security, transparency and comprehensive efficiency of bank operations, is increasing. The answer to these requirements and the step to restore confidence in banks and financial markets was developed by the joint efforts of the OECD, FSB and other international organizations, the High Principles for the Protection of Consumers of Financial Services, which were approved at the G-20 summit in Los Cabos in June 2012, and then adopted by the OECD as recommendations for member countries in July 2012. These principles address issues of openness and publicity in the provision of financial services, responsible behavior of banks, complaints and conflict resolution.

Currently, international practice officially provides for the participation of representatives of financial community, as well as trade unions, consumers of financial services in the discussion of international standards being developed. So, within the framework of the G-20, there are: B-20 (Business Twenty, representing the interests of business, including financial, of the participating countries), L-20 - (Labor Twenty) and C-20 (Civil Twenty), representing the interests of trade unions and civil society. As for international financial organizations and other international structures, there are special advisory committees and commissions whose activities are aimed at developing recommendations, including in the financial sector by business and consumers of financial services. Active participants in discussions on financial security are representatives of associations of financial institutions and their self-regulatory organizations (for example, the Global Banking Association (GBA), the International Swap and Derivatives Association (ISDA), the International Investment Funds Association (IIFA), etc.).

To build confidence in banks and financial markets, it is necessary to strengthen regulatory measures and especially supervision. The development of international cooperation and harmonization of national regulatory practices are significant for global financial institutions as a prerequisite for their sound functioning and cross-border business. 


\section{Research Questions}

Consideration of methodological tools for analyzing current trends in global financial regulation of financial and credit institutions and assessing the main purpose - strengthen the stability of financial markets to ensure sustainable economic growth - allows you to focus on the need for further scientific and practical development of identified issues. The main areas of research are:

- Analysis of the main problems and contradictions of the modern international banking regulation system;

- Assessment of the consequences and prospects for the implementation of recommendations of Basel Accords (Basel III) in the short and long term.

\section{Purpose of the Study}

The purpose of the study is to develop the main directions for improving Basel Accords for the regulation and supervision of credit organizations. The issues of improving banking regulation are debatable, since excessive strengthening of supervision can undermine competition and vice versa: weakening of the regulation can negatively affect the stability of financial and credit institutions. In these circumstances, it is necessary to monitor prudential reforms in order to minimize negative consequences for the economy and at the same time maintain healthy competition in the financial markets.

\section{Research Methods}

The study suggests practically oriented approach to the development of Basel Accords to ensure financial stability at the macro- and microeconomic level. In the course of research, relevant scientific tools were used, in particular, such methods as scientific abstraction, systematization and grouping, data extrapolation, comparative and expert analysis.

In accordance with the set goal, the author proposes a practically oriented approach to the development of the Basel agreements to ensure the financial stability of banks at the macro - and microeconomic level. In the course of the research, the author used relevant scientific tools for the analysis of banks activity, in particular, such methods as scientific abstraction, systematization, analysis and synthesis, classification and grouping, extrapolation of data. Retrospective, trend and factor analysis were also used in the research process. Comparative and expert analysis of the Basel agreements (I, II and III) allowed assessing the adequacy of measures applied by financial regulators to ensure the stability of banking systems and individual financial and credit institutions in the national and global dimensions.

\section{Findings}

The need to tighten existing regulatory requirements became apparent during the implementation of Basel II against the backdrop of the global financial and economic crisis that began in 2007 as a mortgage crisis in the United States and then spread to other countries. It gave rise to many new risks, including the risks of "infection" and insolvency, which revealed the failure of existing risk management systems and the lack of regulatory and supervisory coordination between financial, currency and macroeconomic regulators. Despite the fact that recommendations of Basel III were aimed at solving the above problems, a number of issues remain relevant for finding optimal solutions. In this regard, it is advisable to highlight the following main areas for improving Basel III [5].

1) Increasing the normative indicator of financial leverage. In countries that have introduced increased requirements for the debt ratio (EU, USA and some Asia-Pacific countries), as a rule, it is $5 \%$ instead of $3 \%$ proposed by the Basel Committee on Banking Supervision. Proponents of toughening this standard argue that uncertainty in financial markets is more appropriate to measure with simple and commensurate indicators than using complex probabilistic statistical models [6].

2) Simplification and transparency of advanced IRB. To use the advanced IRB system, banks need external, statistically sound information about historical default levels for different groups of borrowers. But at present, banks do not have sufficient empirical data on this issue, which has led to the rejection at the present stage of the widespread use of such risk assessment methods.

3) Increasing the role of liquidity ratios in assessing the results of stress tests. The devastating consequences of the global financial and economic crisis of 2007-2009 and, in particular, the collapse of the investment bank Lehman Brothers demonstrated that risk, which begins as market or credit, develops in a crisis of inadequate liquidity and becomes a problem for financial markets. As a result, issues of ensuring the liquidity of banks are currently receiving increased attention in national and international financial markets.

4) Further tightening regulation of global systemically important banks, including an increase in the premium for systematization. In this regard, the experience of developing an orderly bankruptcy procedure (living wills) for systemically important financial corporations in the USA, implemented by the Federal Deposit Insurance Corporation if necessary and not involving additional expenses of taxpayers is interesting. The law requires bank holdings with assets 
in excess of $\$ 50$ billion, as well as banks and non-banking financial companies whose bankruptcy can seriously damage the US economy, to provide regular reports on how quickly and correctly conduct liquidation procedures. It is believed that this requirement should create incentives for companies to simplify their organizational structures and solve the problem of the emergence of too large financial institutions, the bankruptcy of which could negatively affect the state of the economy as a whole. In the Russian Federation, this approach was implemented by the Bank of Russia in the process of creating the Banking Sector Consolidation Fund and adopting rules for the development and implementation of financial recovery plans for commercial banks.

5) Decrease in the level of procyclicality and provision of countercyclical reserves in the form of capital buffers. In particular, the Bank of Russia uses a credit gap - the difference between the ratio of the volume of credit supply to GDP and the long-term trend of this ratio, determined in accordance with the methodology proposed by the Basel Committee on Banking Supervision. In addition, the Bank uses a long-term equilibrium model of lending, a model for assessing the length of the credit cycle, a model of supply and demand for credit.

In general, the activities of the Basel Committee on Banking Supervision are aimed at the development and continuous improvement of supervisory tools and standards of macroprudential regulation, including the expansion of cross-country information exchange and mutual supervision. Thus, Basel III aims to strengthen international standards for managing capital and liquidity of banks to increase the stability of the banking sector, as well as to improve the ability of banks to overcome the effects of financial and economic crises and thus reduce the risk of these problems spreading from the financial to the real sector of the economy.

Basel III is innovative in nature, as it provides for changes in approaches to financial management and risk management by improving risk management standards, the degree of integration of financial and risk management of banks. It aims to provide a stable base and the necessary reserves to counter potential risks and crises, as well as to form a more complete, consolidated business model for shareholders and management. These changes can be divided into the following areas:

Improving the quality and amount of capital - the document substantially toughens the requirements for the structure and quality of the bank's capital base to increase the ability of banks to absorb losses in both normal and liquidation scenarios, proposes new minimum requirements to equity and first-level capital, new requirements to capital of the first and second levels, a gradual departure from various hybrid instruments, a list of possible deductions from the capital base. New standards for liquidity management, increased coverage of short-term liquidity - Basel III defines liquidity requirements, liquidity standards, minimum liquidity requirements, and a system of monitoring tools [7]. Increasing stable long-term financing - Basel III introduces the Net Stable Funding Ratio (NSFR) to stimulate and motivate banks to attract stable sources of financing for their own operations, as well as to reduce their dependence on short-term funding.

Full-scale risk coverage and risk coverage. Basel III provides for full coverage of risks, increasing capital requirements for covering risks that are not adequately reflected in Basel II, and also provides for an increase in requirements for bank trading portfolios, securitization operations and transactions with derivative securities [8]. To regulate systemically important banks, additional requirements are introduced to the level of adequacy of their capital.

\section{Conclusion}

Basel III acts as the result of the interaction of various forces and interests. The analysis shows that international financial institutions have been able to achieve some progress in developing international banking regulation standards. The growth of global banks' capitalization has been mainly due to retained earnings. Large international banks increased the average capital adequacy ratio of CET1 in accordance with Basel Accords III from 7 to $11 \%$, which exceeds the normative level of 2019. This process is accompanied by a reduction in risk-weighted banking assets, which indicates an increase in the stability of banks. At the same time, the share of risky assets in the currency structure of the bank's balance is decreasing, which confirms the tendency to transfer part of operations to the non-banking sector. In order to ensure guaranteed profits for capitalization growth, many banks have preferred the traditional banking business model in recent years. Disputes about the possible consequences of new regulatory measures for the development of the global economy do not subside. The Basel Committee predicts the absence of a significant long-term negative effect from tightening banking regulation standards, since positive results will be more significant than costs. The introduction of Basel III standards, emphasized in the BIS Annual Report, will benefit banks and the financial system as a whole, and, therefore, serve as the basis for economic growth.

The analysis of the main problems and contradictions of the modern international system of financial regulation allowed us to draw the following conclusions. First, in order to strengthen the stability of the financial sector, it is necessary to cooperate and be able to find compromises taking into account the interests of all participants: global and national regulators, banks and their customers, which is of particular importance for ensuring sustainable growth of the global economy. Secondly, despite the differences in quantitative assessments of the effects of Basel III, the banking sector is currently facing serious challenges in the short and long term. In the short term, banks should clear their balance sheets from bad assets, and it requires decommissioning and subsequent recapitalization. This measure will allow banks to restore customer confidence and strengthen their market position. And in the long run, banks must restructure their business models by conducting more cost-sensitive accounting, preferring a strategy of lower, but more stable profits, in order to maintain their financial stability while working in the new regulatory environment. 
Basel III represents a fundamental strengthening of global banking standards and is the foundation of long-term financial stability and economic growth. However, tight regulation threatens economic growth. According to the estimates of the Basel Committee, the average global GDP growth rate will be lower by $0.04 \%$ over 4 - 5 years due to the introduction of new rules. In addition, there is a threat of financial sector contraction, as not all banks will be able to withstand new capital adequacy standards. The adoption of Basel III, assuming the attraction of additional funds by banks, decreases their profitability and increases the cost of borrowing. In this regard, an increase in interest rates on loans is possible, which may have a negative impact on economic recovery. As a result, it is possible to intensify the process of bank mergers and acquisitions, which will inevitably weaken competition in the banking sector. On the other hand, the standards of Basel III in the calculation of liquidity ratios imply an increase not only in capital, but also in assets. The introduction of new capital requirements in the United States and Western Europe may provoke a capital shortage and a decrease in bank leverage. Under these conditions, banks will be forced to slow down lending, and existing assets should be taken into account on the balance sheet (especially within financial holdings). An increase in the requirements for equity will lead to a decrease in its profitability, which means a simultaneous decrease in the attractiveness of investments in bank capital and an increase in the need for capital. Thus, the introduction of these measures is pro-cyclical in nature and may lead to a deepening recession in the economy. Moreover, in the new international standards of banking capital, the supervisory component is not sufficiently developed. And to ensure the financial stability of banks, it is not enough to tighten the requirements for equity. Therefore, in addition to raising capital standards, it is necessary to take measures aimed at improving the quality of assets, creating a liquidity reserve and improving the management of banks. However, the economic benefits of Basel III prevail. The main goal of Basel standards is to increase the stability of banks and protect the rights of consumers of financial services. It means that international standards are aimed at ensuring the stability of financial markets, reducing risks and reducing the likelihood of future crises, which will allow banks to independently (without government support) withstand financial shocks of such magnitude as crisis of 2008-2009. These advantages are not only a factor in strengthening the banking system in the long term, but also increase confidence in the financial stability of banks.

\section{References}

1. L.S. Khudyakova, The international experience in the struggle with manipulated transactions in financial markets. Money and Credit, 7, 65-70 (2011). [in Rus.].

2. B. Eichengreen, International financial regulation after the crisis. Daedalus Fall, 139(4), 107-114 (2010).

3. C.H. Dallara, Containing extraterritoriality to promote financial stability. Financial Stability Review, 17, 47-59 (2013).

4. H. Davies, Global financial regulation after the credit crisis. Global Policy, 1(2), 185-190 (2010).

5. Basel Committee on Banking Supervision, Basel III: A global regulatory framework for more resilient banks and banking systems (Bank for International Settlements Communications, Basel, 2011).

6. KPMG, Basel 4 revisited: The fog begins to clear (2015). URL: https://assets.kpmg/content/dam/kpmg/pdf/2015/10/basel-4-report-concepts.pdf. Accessed: 21.10.2019.

7. Basel Committee on Banking Supervision, Proposal to ensure the loss absorbency of regulatory capital at the point of non-viability (Bank for International Settlements Communications, Basel, 2010).

8. Basel Committee on Banking Supervision, Proposal to ensure the loss absorbency of regulatory capital at the point of non-viability - consultative document (Bank for International Settlements Communications, Basel, 2010). 